THE CANADIAN JOURNAL OF AUTISM EQUITY

LA REVUE CANADIENNE DE L'ÉQUITÉ EN MATIÈRE D'AUTISME

\begin{tabular}{l|l|l} 
VOLUME 1 & ISSUE 1 & APRIL 2021
\end{tabular}

\title{
A Call for Expanding the Diversity of Voices in Autism Research Engagement
}

Mackenzie Salt, McMaster University, Canada

RECOMMENDED CITATION: Salt, M. (2021). A Call for Expanding the Diversity of Voices in Autism Research Engagement. The Canadian Journal of Autism Equity, 1(1), 46-48. 


\title{
A Call for Expanding the Diversity of Voices in Autism Research Engagement
}

\author{
Mackenzie Salt ${ }^{1}$
}

\begin{abstract}
Recently, there has been a push to increase research engagement within the autism community. Historically, research engagement has largely focused on childhood disability research and participatory autism research remains rare (den Houting et al., 2021). This gap in the literature can often result in the substitution of parents' voices for those of their Autistic children within the

framework of family-centred services. This article argues that research

engagement should be conducted in a way that can represent the wider autism community and cautions against allowing voices of one element of the autism community to speak for the whole.

Résumé

Récemment, la communauté de l'autisme a exercé des pressions pour accroître sa participation à la recherche. Historiquement, l'engagement de

la recherche s'est largement concentré sur le handicap infantile, et la recherche participative sur l'autisme reste rare (den Houting et al., 2021).

Cette lacune dans la littérature scientifique peut souvent entraîner la substitution des voix des parents à celles de leurs enfants autistes dans le cadre des services centrés sur la famille. Cet article soutient que l'engagement dans la recherche devrait être mené de manière à représenter la communauté de l'autisme dans son ensemble. Il met également en garde contre le fait de permettre aux voix d'un élément de la communauté de l'autisme de parler au nom de tous ses membres.
\end{abstract}

Keywords

Autism, Participatory Research, Research Ethics, Equity, Diversity Mots clés

Autisme, Recherche Participative, Éthique de la Recherche, Équité, Diversité

1 McMaster University, Canada 
Over the last decade, there has been an increase in the practice of involving participants from a research population in aspects of research beyond just participation. This practice has been called, among other names, family engagement in research, family-centred research, codesign, co-research, patient-oriented research, participatory action research, and participatory research (Canadian Institutes of Health Research, 2014; den Houting et al., 2021; Moll et al., 2020; Rosenbaum, 2011; Shen et al., 2017). One of the areas that has embraced this type of research the most has been childhood disability research. This is largely because this type of research came out of family-centred service, wherein families "are seen as experts on their children, and professionals are encouraged to work with them in partnership to address the family's issues" (Rosenbaum, 2011, p. 99). Family-centred service was originally proposed in the 1940s, but it was not until the 1960s when the concept was adopted and expanded by organizations, such as the Association for the Care of Children's Health (Rosenbaum et al., 1998, p. 3). More recently, the Canadian Institutes of Health Research (2014) has adopted a framework for conducting patient-oriented research within a broader scope providing resources to allow patients to be active partners in health research. However, the practice is still largely confined to research in paediatric disabilities and neurodevelopmental conditions. Despite these areas of focus, this practice continues to be rare in autism research (den Houting et al., 2021, p. 2). While this type of research is well-intended, it is not always conducted in ideal circumstances. Especially as it relates to autism, family engagement is often in actuality only parental engagement.

It is important to note that working with parents is not necessarily a bad thing, and it can be extremely helpful to engage parents with certain topics of study. However, to properly account for the patient's perspective, it is important to engage the patient as well, not just the parent. As stated by Fletcher-Watson et al. (2019) in their paper on the importance of participatory autism research:

Historically, parents of autistic children have been listened to somewhat, and autistic people less so. Parents, like practitioners and third-sector workers, can advocate on behalf of their children and may often be stakeholders in research themselves .... Nevertheless, consultation with parents of children on the autism spectrum should not happen to the exclusion of autistic people themselves. (p. 950)

The true issue arises when one substitutes the viewpoints and priorities of parents of children on the autism spectrum for those of Autistic people. For example, in the research study conducted by Clark and Adams (2020), while the autism community is identified as being made up of parents, Autistic people, allied health professionals and educators, their study identifies priority areas for autism research only by engaging the parents of Autistic school-aged children (pp. 1, 5-6). The average ages of the children in primary and secondary school of parents in this study were 9 and 14 respectively (p. 7). In terms of what their goal is in conducting their study, the authors note that "the research priorities of parents of school-aged children are largely understudied and consequently, the understanding of what the research priorities should be for school-aged children on the autism spectrum is currently limited" (p. 3). When discussing the implications of the results of their study, the authors note that " $[t]$ he current findings have important implications for the future of autism research and the delivery of services offered to individuals living with autism and their families" (p. 16). While the researchers acknowledge that 
“it was not possible to capture children's research priorities in the current study, presenting an important area for future research" (p. 14) with no further details, the larger issue is that the researchers prioritized parental perspectives in determining future autism research agendas for school-aged Autistic children. I am confident that at least some of the children of the parents involved in this study would have been capable of responding to a survey about what priorities they would like to see in autism research if given the chance or choice, potentially yielding far different results.

The idea of taking a parent's judgement over that of their child in a research context has a long history in research ethics. Since 1977, to conduct research involving children in the United States, it has been a requirement that children over the age of 7 assent to participate in the research (Carroll \& Gutmann, 2011, p. 84). However, prior to this point, parental consent was all that was required for a child to be subjected to research and experimentation (Carroll \& Gutmann, 2011, p. 92). While I do not believe that current issues with research engagement in the autism community are equivalent to issues of consent or assent in research, it is important that parental voices do not replace the voices of their Autistic children or other Autistic self-advocates in research engagement. Autism is a heterogeneous condition; proper engagement requires a diversity of voices and perspectives to truly represent the autism spectrum and the greater autism community.

\section{ORCID iD}

Mackenzie Salt (iD https://orcid.org/0000-0001-9704-8155

\section{References}

Canadian Institutes of Health Research. (2014). Strategy for patient-oriented research: Patient engagement framework. Canadian Institutes of Health Research. https: //cihr-irsc.gc.ca/e/48413.html

Carroll, T. W., \& Gutmann, M. P. (2011). The limits of autonomy: The Belmont Report and the history of childhood. Journal of the History of Medicine and Allied Sciences, 66(1), 82-115. https://doi.org/ 10.1093/jhmas/jrq021

Clark, M., \& Adams, D. (2020). Listening to parents to understand their priorities for autism research. PLoS ONE, 15(8), 1-20. https://doi.org/10.1371/journal.pone.0237376

den Houting, J., Higgins, J., Isaacs, K., Mahony, J., \& Pellicano, E. (2021). 'I'm not just a guinea pig': Academic and community perceptions of participatory autism research. Autism, 25(1), 148-163. https: / /doi.org/10.1177/1362361320951696

Fletcher-Watson, S., Adams, J., Brook, K., Charman, T., Crane, L., Cusack, J., Leekam, S., Milton, D., Parr, J. R., \& Pellicano, E. (2019). Making the future together: Shaping autism research through meaningful participation. Autism, 23(4), 943-953. https: //doi.org/10.1177/1362361318786721

Moll, S., Wyndham-West, M., Mulvale, G., Park, S., Buettgen, A., Phoenix, M., Fleisig, R., \& Bruce, E. (2020). Are you really doing ‘codesign'? Critical reflections when working with vulnerable populations. BMJ Open, 10(11), 1-5. https: / / doi.org/10.1136/bmjopen-2020-038339

Rosenbaum, P. (2011). Family-centred research: What does it mean and can we do it? Developmental Medicine \& Child Neurology, 53(2), 99-100. https://doi.org/10.1111/j.1469-8749.2010.03871.x

Rosenbaum, P., King, S., Law, M., King, G., \& Evans, J. (1998). Family-centred service. Physical \& Occupational Therapy in Pediatrics, 18(1), 1-20. https: //doi.org/10.1080/J006v18n01 01

Shen, S., Doyle-Thomas, K. A. R., Beesley, L., Karmali, A., Williams, L., Tanel, N., \& McPherson, A. C. (2017). How and why should we engage parents as co-researchers in health research? A scoping review of current practices. Health Expectations, 20(4), 543-554. https://doi.org/10.1111/hex.12490 